\title{
Reaction of Ferralsol to Acidifying Effect of Nitrogen Fertilisation
}

\author{
John Stephen Tenywa*, Jean Bosco Ngarukiyimana, Alice Amoding Katushabe \\ College of Agricultural and Environmental Sciences, Makerere University, Kampala, Uganda \\ Email: ^johntenywa@gmail.com, ^jstenywa@caes.mak.ac.ug
}

How to cite this paper: Tenywa, J.S., Ngarukiyimana, J.B. and Katushabe, A.A. (2021) Reaction of Ferralsol to Acidifying Effect of Nitrogen Fertilisation. Journal of Agricultural Chemistry and Environment, 10, 69-79.

https://doi.org/10.4236/jacen.2021.101005

Received: May 27, 2020

Accepted: January 24, 2021

Published: January 27, 2021

Copyright $\odot 2021$ by author(s) and Scientific Research Publishing Inc. This work is licensed under the Creative Commons Attribution International License (CC BY 4.0).

http://creativecommons.org/licenses/by/4.0/

\begin{abstract}
Background: The objective of this study was to determine the short-term effect of urea fertiliser application on soil reactions in a Ferralsol, with particular thrust on P sorption. Methods: Two experiments were conducted for this purpose: 1) a screenhouse pot experiment; and 2) a laboratory P sorption component. The pot (10 litre capacity plastic pots) experiment was conducted at the Makerere University Agricultural Research, Kabanyolo in Uganda, using a Ferralsol. The study comprised of four urea $\mathrm{N}(46 \% \mathrm{~N})$ fertiliser treatments, namely, 0, 40, 80 and $120 \mathrm{~kg} \mathrm{~N} \cdot \mathrm{ha}^{-1}$, equivalent to $0,200,400$ and 600 mg $\mathrm{N}$ per pot. A completely randomised design was adopted with three replicates. Urea rates were applied in 50\% split doses, one at planting and the other at 19 days after seedling emergence (to simulate farmer practice). This was followed by watering to field capacity using distilled water. Soil samples were taken at three daily intervals until day fourteen; thereafter, soil sampling was at an interval of seven days. The second urea split dose was applied at 21 days followed by soil sampling at an interval of three days till day fourteen. Thereafter, soil was sampled at seven day intervals until the end of experiment. Soil samples were analysed for exchangeable $\mathrm{H}^{+}, \mathrm{Al}^{3+}, \mathrm{NH}_{4}^{+}$and $\mathrm{NO}_{3}^{-}$ ions. The reaction trends of the concentrations of these ions and Bray $1 \mathrm{P}$ were used to structure different response curves representing the instantaneous reactions. As for the laboratory P-sorption study, treatments included the four rates of urea used in the pot experiment $\left(0,40,80\right.$ and $\left.120 \mathrm{~kg} \mathrm{~N} \cdot \mathrm{ha}^{-1}\right)$ and seven levels of $\mathrm{P}(2.5,5,10,20,30,40$ and $50 \mathrm{ppm})$ as $\mathrm{KH}_{2} \mathrm{PO}_{4}$. The setup was incubated under laboratory conditions and soil samples were repeatedly taken at 10 days (after 4 days of urea incubation plus 6 days of $P$ application). The P sorption data were fitted to Langmuir model. Results: The pot experiment revealed an abrupt drop in the concentrations of exchangeable $\mathrm{Al}^{3+}$ and $\mathrm{H}^{+}$ions $(\mathrm{p}<0.05)$ within the first 6 days after urea application, accompanied by a positive surge in the concentration of $\mathrm{NH}_{4}^{+}$ions. This phase (6 days)
\end{abstract}


was followed by a rise in the levels of exchangeable $\mathrm{Al}^{3+}, \mathrm{H}^{+}$and $\mathrm{NO}_{3}^{-}$ion concentration, which was inversely mirrored by a drop in the concentration of $\mathrm{NH}_{4}^{+}$ions. Consequently, the patterns displayed by the soil reactions were delineated into four phases, with Phase 1 ( 6 days) being characterised by urea hydrolysis reactions of deamination and ammonification, Phase 2 (10 days) being dominated by nitrification and its acidifying properties, Phase 3 being a repeat of Phase 1, both occurring immediately after urea application (within 6 days); and Phase 4 being a repeat of Phase 2. As for the P-sorption study, the effects of urea hydrolysis in a Ferralsol markedly increased soil $\mathrm{pH}$ and surprisingly $\mathrm{P}$ sorption. The contradictory $\mathrm{P}$ sorption behavior, despite the drop in exchange acidity was attributed to presence of divalent calcium in the extraction reagent used. Conclusion: The short term insights obtained in response to urea $\mathrm{N}$ application in the Ferralsol, are eye openers to future use of $\mathrm{N}$ fertilisers as well as strategic management of the associated acidification process which is often more costly and complicated to manage.

\section{Keywords}

Urea Hydrolysis, Ammonification, Phosphorus Sorption

\section{Introduction}

There is a mixed bag of farming community views about the value of nitrogen fertilisers in boosting crop production sub-Saharan Africa (SSA), despite the decision by regional governments to use fertilisers to unlock food insecurity and poverty in the region. The situation has further been confounded by organic movementists who unlimitedly detest the use of inorganic fertilisers [1], for reasons largely related to environmental health. Most $\mathrm{N}$ fertilisers are blamed for causing devastating soil acidity, nitrate leaching losses and its attendant aluminium toxicity and $\mathrm{P}$ sorption in the long run [2]. Unfortunately, there is hardly any knowledge about the dynamics of the reactions that partake in the short-run soon after application of $\mathrm{N}$ fertilisers, particularly in a typical tropical acid soil.

Ferralsols constitute approximately $60 \%$ of the arable soils in SSA [3]; moreover with $\mathrm{pH}$ ranging from 3.6 to 4.8 , which is substantially acidic [4]. A significant change in soil acidity caused by nitrification of $\mathrm{N}$ fertilisers may induce a series of reactions in the soil, which may subsequently reduce the availability of some nutrients, cause excessive solubilisation of some micronutrients $(\mathrm{Mn}, \mathrm{Cu}$, $\mathrm{Fe}$, etc.), and consequently, $\mathrm{Al}^{3+}$ phytotoxicity. Eriksen and Kjeldby (1987) [5] observed that up to $52 \%$ of urea is converted into nitrate within three days after application to the soil; although there is paucity of information on soil type and threshold soil acidity. Although it is clear that nitrification of a single ammonium ion potentially results in four protons in the soil, and consequently deterioration in soil acidity; the directions taken by reactions that partake shortly after application of urea in a Ferralsol remain to be established. Some of the favoura- 
ble reactions may the basis for envisioning whether to invest in costly liming programmes to mitigate the resulting acidification effect, or to preserve the short-lived favourable micro-environment caused by some reactions, against the propensity to the nitrification process. The objective of this study was, therefore, to 1$)$ determine the short term responsive reactions to urea fertiliser application in a tropical acidic; and 2) characterise P during the short term phase after urea fertiliser application.

\section{Materials and Methods}

This study comprised of two parts, namely a screenhouse experiment and a laboratory P sorption experiment.

\subsection{Screenhouse Experiment}

The screenhouse experiment was conducted using a Ferralsol collected from the Makerere University Agricultural Research Institute, Kabanyolo (MUARIK) in Uganda. Plastic pots of 10 litre capacity $(22.57 \mathrm{~cm}$ of diameter and $25.00 \mathrm{~cm}$ of height), were each filled with $5 \mathrm{~kg}$ of air dried soil. To permit air circulation within the pots, each pot was perforated on all sides and at the bottom using a hot nail.

Treatments comprised of four rates of urea (46\%), namely 0, 200, 400 and 600 mg of urea per pot (equivalent to $0,40,80$ and $120 \mathrm{~kg} \mathrm{~N} \cdot \mathrm{ha}^{-1}$ ), applied in $50 \%$ split doses, one at planting and the remainder two weeks thereafter. Prior to application, urea granules per treatment were dissolved in approximately $40 \mathrm{ml}$ of distilled water, and then applied at a radius of about $5 \mathrm{~cm}$ around the central position of the pot. The treatments were arranged in a completely randomised design (CRD) and replicated three times. The study was repeated thrice.

During the study, soil sub-samples were taken from each pot initially at of three day-intervals, till fourteen days. Thereafter, further soil sampling was done at intervals of seven days till the end of experiment (... days). The process of urea administration and subsoil sampling were repeated starting at 19 days after application of the second split dose in the same pots. The sub-samples obtained were air-dried for seven days, ground using a porcelain motor and pestle, before being subjected to analysis for exchangeable $\mathrm{H}^{+}$and $\mathrm{Al}^{3+}$, and mineral $\mathrm{N}$ (nitrate and ammonium) species (Table 1).

\subsection{Laboratory Study}

As for the laboratory P-sorption study, treatments included the four rates of urea

Table 1. Baseline physico-chemical characteristics of soil used in the study.

\begin{tabular}{|c|c|c|c|c|c|c|c|c|c|c|}
\hline Parameters & $\mathrm{pH}$ & $\mathrm{Al}$ & $\mathrm{NO}_{3}^{-}$ & $\mathrm{NH}_{4}^{+}$ & Av. P & $\mathrm{K}^{+}$ & $\mathrm{Ca}^{2+}$ & $\mathrm{Mg}^{2+}$ & OC & Soil textural name \\
\hline Units & & \multicolumn{4}{|c|}{$\mu \mathrm{g} \cdot \mathrm{g}^{-1}$} & \multicolumn{3}{|c|}{ cmoles $\cdot \mathrm{kg}^{-1}$} & & $\%$ \\
\hline Values & 4.18 & 240 & 4.13 & 8.87 & 0.18 & 0.44 & 8.30 & 4.40 & 1.80 & Sandy clay loam \\
\hline Critical values & 5.50 & & & & 15 & 0.33 & 4.00 & 0.25 & 3.00 & \\
\hline
\end{tabular}


used in the pot experiment $\left(0,40,80\right.$ and $\left.120 \mathrm{~kg} \mathrm{~N} \cdot \mathrm{ha}^{-1}\right)$ and seven levels of $\mathrm{P}(2.5$, $5,10,20,30,40$ and $50 \mathrm{ppm}$ ) as $\mathrm{KH}_{2} \mathrm{PO}_{4}$. The setup was incubated under laboratory conditions and soil samples were repeatedly taken at 10 days (4 days after urea application plus 6 days after $\mathrm{P}$ application). The $\mathrm{P}$ sorption data were fitted to Langmuir model, which was used to obtain equilibrium $\mathrm{P}$ concentration $(\mu \mathrm{g}$ $\mathrm{P} \cdot \mathrm{ml}^{-1}$ ), adsorption maximum ( $\mu \mathrm{g} \mathrm{P} \cdot \mathrm{g}^{-1}$ soil), and bonding energy constants.

\subsection{Statistical Data Analysis}

Data collected from both study parts were subjected to analysis of variance (ANOVA) using $\mathrm{R}$ version 3.4.3; while significantly different treatment means were separated using the Tukey's Honestly Significant Difference.

\section{Results}

\subsection{Exchangeable Hydrogen and Aluminium}

There was a marked effect $(\mathrm{p}<0.05)$ of rate of urea $\mathrm{N}$ on the $\left[\mathrm{H}^{+}\right]$ions during incubation of the soil (Figure 1). Initially, with the exception of the control where urea was not applied, all treatments realised a drastic depression $(\mathrm{p}<$ $0.05)$ in the $\left[\mathrm{H}^{+}\right]$for about 9 days, with the highest two urea rates $(80$ and $120 \mathrm{~kg}$ $\mathrm{N} \cdot \mathrm{ha}^{-1}$ ) causing the greatest effect. After about 9 days of incubation, the $\left[\mathrm{H}^{+}\right]$ short up until the second urea split dose was applied at 19 days of incubation. From that point onwards, there was again a slumped in $\left[\mathrm{H}^{+}\right]$, mirroring that of the initial 6 days. Based on the behavioral patterns of the $\left[\mathrm{H}^{+}\right]$, the trends were partitioned into four phases, hereafter codenamed Phase 1 ( 9 days), Phase 2 (10 days), Phase 3 (10 days) and Phase 4 (long term) (Figure 1).

The concentration of exchangeable $\mathrm{Al}^{3+}$ displayed a similar trend to $\left[\mathrm{H}^{+}\right]$in response to urea application (Figure 2). Generally, the levels of exchangeable $\left[\mathrm{Al}^{3+}\right]$ were higher for the control and $40 \mathrm{~kg} \mathrm{~N} \cdot \mathrm{ha}^{-1}(238.67 \pm 0.20$ and $239.65 \pm$

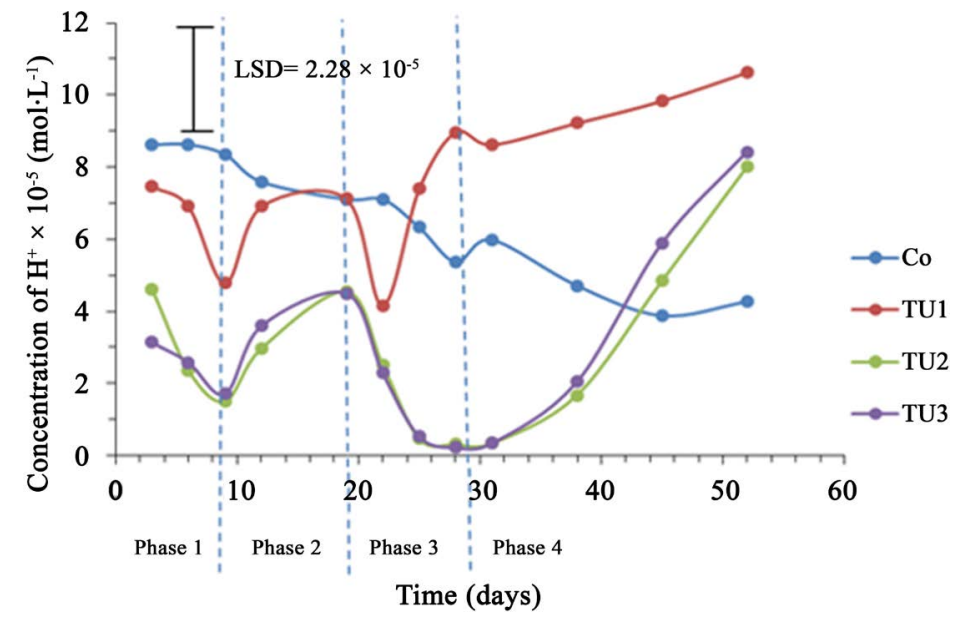

Figure 1. Changes in the concentration of $\left[\mathrm{H}^{+}\right]$in a Ferralsol induced by different rates of urea application, during incubation. $\mathrm{Co}=$ no $\mathrm{N}$ applied, TU1 $=40 \mathrm{~kg} \mathrm{~N} \cdot \mathrm{ha}^{-1}$, TU2 $=80 \mathrm{~kg}$ $\mathrm{N} \cdot \mathrm{ha}^{-1}$, TU3 $=120 \mathrm{~kg} \mathrm{~N} \cdot \mathrm{ha}^{-1}$. Phase $1=$ Short phase 1 , Phase $2=$ Medium term phase, Phase 3 = Short term phase 2 , Phase $4=$ Long term phase. 
$0.36 \mu \mathrm{g} \cdot \mathrm{g}^{-1}$, respectively), than in the urea rates of 80 and $120 \mathrm{~kg} \mathrm{~N} \cdot \mathrm{ha}^{-1}(229.13 \pm$ 0.87 and $228.79 \pm 0.97 \mu \mathrm{g} \cdot \mathrm{g}^{-1}$, respectively), for the initial duration of about 9 days. Thereafter, the concentration of $\mathrm{Al}^{3+}$ surged to the extent that the effect of the highest urea rates exceeded that of urea at the rates of 0 and $40 \mathrm{~kg} \mathrm{~N} \cdot \mathrm{ha}^{-1}$.

\subsection{Ammonium and Nitrate Concentrations}

The concentrations of ammonium ions in the Ferralsol after application of different rates of urea are presented in Figure 3. In contrast with both $\left[\mathrm{H}^{+3}\right]$ and $\left[\mathrm{Al}^{3+}\right]$, the concentration of $\mathrm{NH}_{4}^{+}$tended to surge with application of urea, lasting for the initial period of 9 days during incubation. Consequently, the

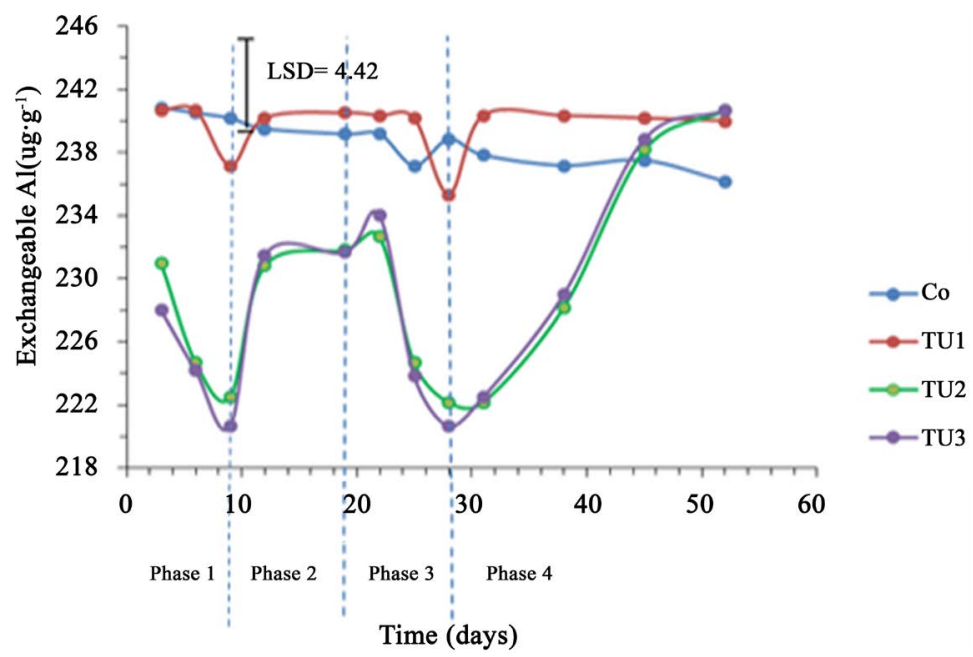

Figure 2. Changes in exchangeable Aluminium induced by different urea concentrations over time. Co $=$ control, TU1 $=40 \mathrm{~kg} \mathrm{~N} \mathrm{ha}^{-1}$, TU2 $=80 \mathrm{~kg} \mathrm{~N} \cdot \mathrm{ha}^{-1}$, TU3 $=120 \mathrm{~kg} \mathrm{~N} \cdot \mathrm{ha}^{-1}$. Phase $1=$ Short phase 1 , Phase $2=$ Medium term phase, Phase $3=$ Short term phase 2 , Phase $4=$ Long term phase.

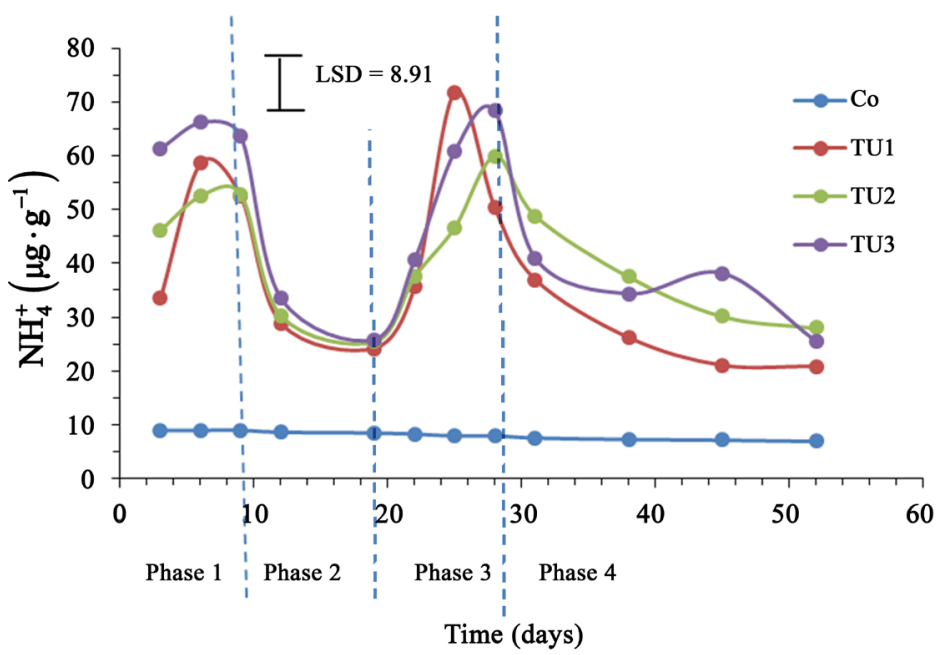

Figure 3. Changes in ammonium ion concentration over the study period under different rates of urea application. Co $=$ control, TU1 $=40 \mathrm{~kg} \mathrm{~N} \cdot \mathrm{ha}^{-1}, \mathrm{TU} 2=80 \mathrm{~kg} \mathrm{~N} \cdot \mathrm{ha}^{-1}, \mathrm{TU} 3=$ $120 \mathrm{~kg} \mathrm{~N} \cdot \mathrm{ha}^{-1}$. Phase $1=$ Short phase 1 , Phase $2=$ Medium term phase, Phase $3=$ Short term phase 2, Phase $4=$ Long term phase. 
highest concentration of $\left[\mathrm{NH}_{4}^{+}\right]$of $46.61 \pm 2.13 \mu \mathrm{g} \cdot \mathrm{g}^{-1}$ was obtained with the highest rate of application $\left(120 \mathrm{~kg} \mathrm{~N} \cdot \mathrm{ha}^{-1}\right)$, and the lowest with the control (8.11 $\left.\pm 0.11 \mu \mathrm{g} \cdot \mathrm{g}^{-1}\right)(\mathrm{p}<0.05)$.

Figure 4 presents the concentration of nitrate ions in the Ferralsol, following application of different rates of urea. Unlike the case of $\mathrm{NH}_{4}^{+}$, the concentration of $\mathrm{NO}_{3}^{-}$ions was trace at the beginning of the study, but gradually built up in the reverse direction with that of $\mathrm{NH}_{4}^{+}$(Figure 5), and was commensurate with the rates applied. The pattern of response of nitrate ions closely followed that of hydrogen (Figure 1) and exchangeable aluminium (Figure 2) ion concentration curves.

\subsection{Phosphorus Sorption}

Urea application generally had a strong and positive effect on P sorption (Figure 6),

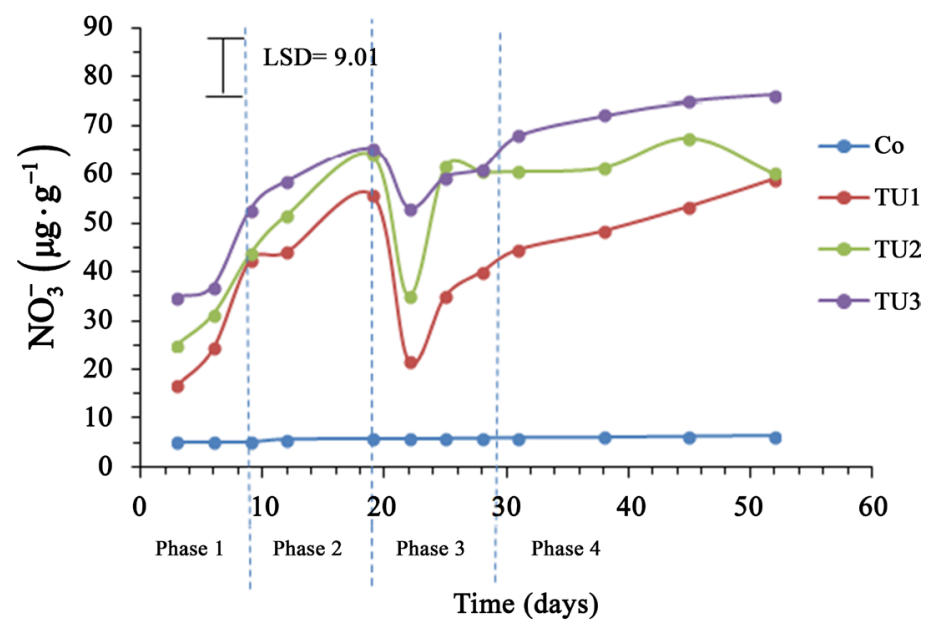

Figure 4. Changes in nitrate ion concentration over the study period under different rates of urea application. $\mathrm{Co}=$ control, TU1 $=40 \mathrm{~kg} \mathrm{~N} \cdot \mathrm{ha}^{-1}, \mathrm{TU} 2=80 \mathrm{~kg} \mathrm{~N} \cdot \mathrm{ha}^{-1}, \mathrm{TU} 3=120 \mathrm{~kg}$ $\mathrm{N} \cdot \mathrm{ha}^{-1}$. Phase $1=$ Short phase 1 , Phase $2=$ Medium term phase, Phase $3=$ Short term phase 2 , Phase $4=$ Long term phase.

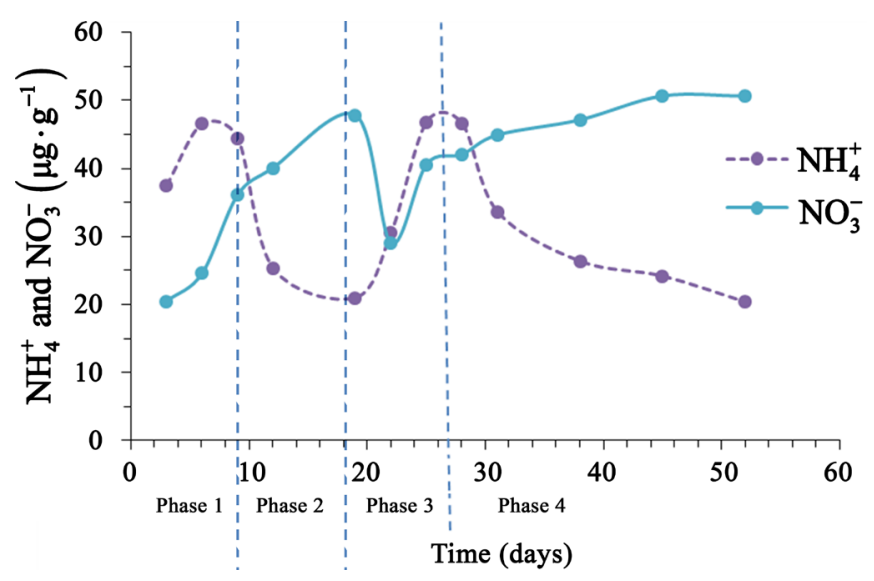

Figure 5. Changes in nitrate and ammonium ion concentration over the study period under different rates of urea application. Phase $1=$ Short phase 1 , Phase $2=$ Medium term phase, Phase $3=$ Short term phase 2 , Phase $4=$ Long term phase. 
in spite of the clear drop in $\left[\mathrm{H}^{+}\right]$and $\left[\mathrm{Al}^{3+}\right]$ concentrations (Figure 1 and Figure 2). Phosphorus was consistently more plant available without than with urea application. The sequence of adsorption isotherms followed the order of urea rates of 0 (control) $<40<80<120 \mathrm{~kg} \mathrm{~N} \cdot \mathrm{ha}^{-1}$; although at the higher rates of urea, the differences between 80 and $120 \mathrm{~kg} \mathrm{~N} \cdot \mathrm{ha}^{-1}$ tended to disappear. Also, the differences between the effects of urea rates 0 (control), 40 and $80 \mathrm{~kg} \mathrm{~N} \cdot \mathrm{ha}^{-1}$ tended to remain constant, throughout the range of $\mathrm{P}$ applied to the centrifuge tubes (Figure 6). It was noted that as the rate of urea increased, Langmuir adsorption maximum capacity of the Ferralsol increased, and so did the phosphorus buffering capacity (Table 2). There was a noticeable increase in soil $\mathrm{pH}$ with increased rate of urea, from $\mathrm{pH} 4.25$ to 5.57. A P sorption maximum capacity of $2.53 \mathrm{mg} \cdot \mathrm{kg}^{-1}$ was obtained in this Ferralsol treated with urea at $120 \mathrm{~kg} \mathrm{~N} \cdot \mathrm{ha}^{-1}$; contrasting with soil without urea, which adsorbed a dismal quantity of $\mathrm{P}$ (1.17 $\mathrm{mg}$ P. $\mathrm{kg}^{-1}$ soil).

\section{Discussion}

\subsection{Screenhouse Study}

The observed reduction in the $\left[\mathrm{H}^{+}\right]$(Figure 1 ) and $\left[\mathrm{Al}^{3+}\right]$ (Figure 2), and simultaneous increase in $\left[\mathrm{NH}_{4}^{+}\right]$(Figure 3 ) in the study Ferralsol, immediately after

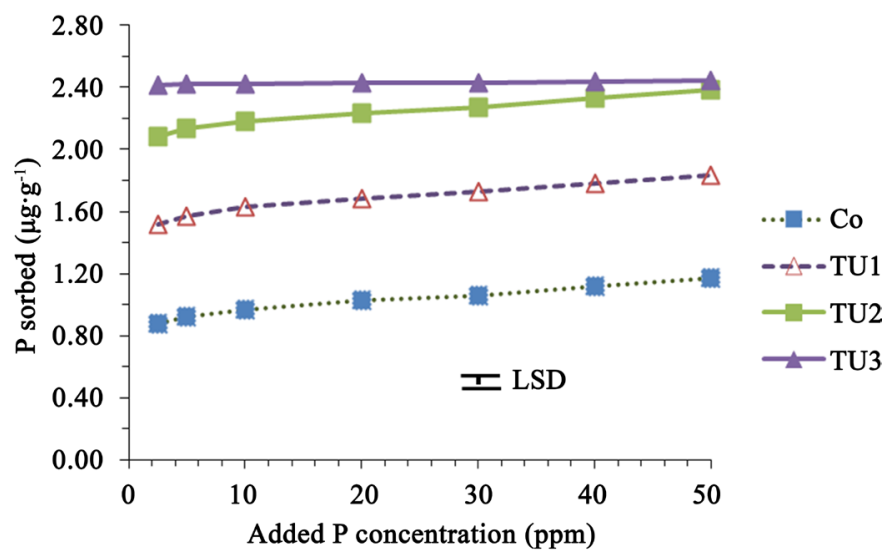

Figure 6. Phosphorus isotherm for ferralsol under different levels of urea based N. Co = control, TU1 = $40 \mathrm{~kg} \mathrm{~N} \cdot \mathrm{ha}^{-1}$, TU2 $=80 \mathrm{~kg} \mathrm{~N} \cdot \mathrm{ha}^{-1}$, TU3 = $120 \mathrm{~kg} \mathrm{~N} \cdot \mathrm{ha}^{-1}$.

Table 2. Effect of urea based $\mathrm{N}$ rates on phosphorus sorption in a Ferralsol.

\begin{tabular}{cccccc}
\hline & & \multicolumn{4}{c}{ Langmuir parameters } \\
\cline { 3 - 6 } $\mathrm{N}$ rates & $\mathrm{pH}$ & $\begin{array}{c}\text { Sorption } \\
\text { maximum (b) }\end{array}$ & $\begin{array}{c}\text { Bonding energy } \\
\text { constant (k) }\end{array}$ & $\begin{array}{c}\text { P buffering } \\
\text { capacity }\end{array}$ & $\mathrm{R}^{2}$ \\
\hline${\mathrm{kg} \cdot \mathrm{ha}^{-1}}$ & & $\mu \mathrm{g} \mathrm{P} \cdot \mathrm{g}^{-1}$ & & $\mu \mathrm{g} \cdot \mathrm{g}^{-1}$ & \\
\hline 0 & 4.25 & 1.17 & 0.60 & 0.70 & 0.99 \\
40 & 4.69 & 1.83 & 1.08 & 1.98 & 0.99 \\
80 & 5.50 & 2.38 & 1.63 & 3.87 & 0.99 \\
120 & 5.70 & 2.53 & 5.03 & 12.73 & 0.98 \\
\hline
\end{tabular}


application of the first dose of urea $\mathrm{N}$ fertiliser, is presumed to be the result of urea hydrolysis, which occurs instantaneously in well drained soils, soon after exposure to the environment. The hydrolysis process consists of de-amination of a urea molecule into two amino groups, both of which are unstable and thus consume free protons from the solution to form ammonia gas, and in turn ammonium ions [6]. Of necessity, the 2 -fold deprotonation per urea molecule results in a drop in exchangeable $\left[\mathrm{H}^{+}\right]$and $\left[\mathrm{Al}^{3+}\right]$, and a subsequent rise in $\left[\mathrm{NH}_{4}^{+}\right]$. The ensuing diminished acidity and $\mathrm{Al}^{3+}$ phytotoxicity could be a better environment for plant growth if sustained, say through use of nitrification inhibitors. The process of urea hydrolysis has been summarised by [7] as follows:

$$
\mathrm{CO}\left(\mathrm{NH}_{2}\right)_{2(\mathrm{~s})}+2 \mathrm{H}_{2} \mathrm{O}_{(\mathrm{l})} \rightarrow\left(\mathrm{NH}_{4}\right)_{2} \mathrm{CO}_{3(\mathrm{~s})} \rightarrow 2 \mathrm{NH}_{3(\mathrm{~g})}+2 \mathrm{OH}_{(\mathrm{aq})}^{-}+\mathrm{CO}_{2(\mathrm{~g})}
$$

The resulting drop in $\left[\mathrm{H}^{+}\right]$and $\left[\mathrm{Al}^{3+}\right]$ ion concentrations due to the buildup of ammonium hydroxide in the soil solution; though short-lived, is likely to have influenced several other soil properties, including availability of some nutrients to plants. For instance, since the pre-experiment soil $\mathrm{pH}$ was 4.18 (Table 1), it can be inferred that $\mathrm{P}$ availability in this Ferralsol was originally restricted; but could be unlocked by the rise urea application to the soil. For most Ferralsols, the widely recognised favourable $\mathrm{pH}$ range for growth of majority of crops is 5.5 $-5.6[8]$.

The favourable plant growth environment generated by urea hydrolysis in this acid soil, plus other associated transformation reactions, appear to underscore the significance of delaying or blocking the onset of the nitrification phase, which is the key player in the deterioration of acid conditions in Ferralsols. In this case, use of nitrification inhibitors to block nitrification need to be explored.

Phase 2, during which there was a rise in $\left[\mathrm{H}^{+}\right]$and $\left[\mathrm{Al}^{3+}\right]$ (9 days after urea application) (Figure 1 and Figure 2), evidently marked the beginning of nitrification, a process that is mediated by enzymes generated by chemotrophic micro-organisms in the soil [9]. Mediated by two sequential enzymes known as ammonia monooxygenase and hydroxylamine oxidoreductase, produced by $\mathrm{Ni}$ trosomonas and Nitrobactor, respectively; this process is aerobic in nature [10]. On the other hand, a higher presence of the ammonium substrate kinetically dictates on the rate of nitrification, and thus accumulation of soil acidity. As such, ammonia oxidation (nitrification) is reportedly inhibited at high substrate concentrations [11] [12]. This, however, does not seem to have occurred in the Ferralsol during the present study.

Among the loremain products of nitrification are four active protons $\left(\mathrm{H}^{+}\right)$per two mols of ammonium ions [13] which are from one mol of urea molecule. Thus, continuous application of urea in the field invariably causes a drop in soil $\mathrm{pH}$ in the medium to long run, especially in the top soil, thus affecting soil reaction and the life of soil inhabitants there in.

The present study has confirmed that the bulk of findings available in literature in relation urea and its effects on endemically acid soils, including Ferralsols [14], are based on medium to long term periods, during which nitrification pre- 
dominates. Moreover, the nitrate $\mathrm{N}$ as the key product of nitrification suffers tremendously from leaching losses, owing to its negative charge, which is repelled by the predominately net negatively charged soil exchange complex. In contrast, under soil submerged conditions, nitrate $\mathrm{N}$ species is lost through denitrification into non-plant available forms e.g., $\mathrm{N}_{2}, \mathrm{~N}_{2} \mathrm{O}$ and $\mathrm{NO}$ [15], some of which as disastrous to the ozone layer [16]. Therefore the action of intervention with nitrification inhibitors may be imperative to saving environmental health as well as achieving favourable agronomic soil conditions.

\subsection{Phosphorus Sorption}

The significant suppressive effect of urea hydrolysis on $\mathrm{P}$ sorption in the present study suggests that the expected gains from the rise in $\mathrm{pH}$ (Table 2) and drop in the $\left[\mathrm{Al}^{3+}\right]$ (Figure 2) achieved shortly after urea application were somehow lost to other processes. This represents a discrepancy with previous studies, whereby urea hydrolysis resulted in increases soil $\mathrm{pH}$, and reduction in $\mathrm{P}$ sorption [17]. It is invariably believed that increasing $\mathrm{pH}$ of acid soils diminishes the concentration of soluble $\mathrm{Fe}$ and $\mathrm{Al}$ [18], which otherwise demobilise plant available $\mathrm{P}$ into polyphosphate complexes [17]. As a result, surface charge should become more negative with $\mathrm{pH}$ increase, thus decreasing the number of $\mathrm{P}$ sorption sites and reducing the strength of $\mathrm{P}$ sorption. This process which should have subscribed to the suppressive effect of $\mathrm{P}$ sorption by the soil, presented a contradictory behavior under the prevailing treatments, quite difficult to explain based on this study. The obtaining urea-P sorption scenario was also obtained by [19], who attributed it to the use of reagents containing divalent cations ( $\mathrm{Ca}$ ) as components of most conventional $\mathrm{P}$ sorption assessment procedures. These divalent cations reportedly affect the sorbent surface charge, as well as the electric potential [20].

\section{Conclusion}

This study has brought into context soil reactions that occur unrecognised in a Ferralsol, in the short run after application of urea to typical tropical acid soils. The main reactions shortly after application of urea $\mathrm{N}$ fertiliser include de-amination and ammonification, which drastically reduce exchangeable $\left[\mathrm{H}^{+}\right]$and $\left[\mathrm{Al}^{3+}\right]$ in the soil. Surprisingly, the process of urea hydrolysis greatly favoured $\mathrm{P}$ sorption, in spite of the expected rise in soil $\mathrm{pH}$. The cause of this discrepancy was attributed to the presence of $\mathrm{CaCl}_{2}$ in the reagents used in the $\mathrm{P}$ sorption studies. Further urea explorative field studies are recommended to confirm the short-term reactions under natural soil conditions, and to estimate the liming equivalents to the urea hydrolysis effects.

\section{Acknowledgements}

This study was generously supported by special people, namely Sarah Lander of Brunswick Canada; Cory Kearns and Coventry Anneliesse of Sydney Australia; 
and Jonathan Cartwright and Charlotte Cartwright of Manchester United Kingdom.

\section{Conflicts of Interest}

The authors declare no conflicts of interest regarding the publication of this paper.

\section{References}

[1] Vanlauwe, B. and Giller, K. E. (2006) Popular Myths around Soil Fertility Management in Sub-Saharan Africa. Agriculture, Ecosystems and Environment, 116, 34-46. https://doi.org/10.1016/j.agee.2006.03.016

[2] Schroder, J.L., Zhang, H., Girma, K., Raun, W.R., Penn, C.J. and Payton, M.E. (2011) Soil Acidification from Long-Term Use of Nitrogen Fertilizers on Winter Wheat. Soil Science Society of America Journal, 75, 957-964. https://doi.org/10.2136/sssaj2010.0187

[3] Deckers, J. (1993) Soil Fertility and Environmental Problems in Different Ecological Zones of the Developing Countries in Sub-Saharan Africa. The Role of Plant $\mathrm{Nu}$ trients and Sustainable Food Production in Sub-Saharan Africa, 37-52.

[4] Dwomo, O. and Dedzoe, C.D. (2010) Oxisol (Ferralsol) Development in Two Agro-Ecological Zones of Ghana: A Preliminary Evaluation of Some Profiles. Journal of Science and Technology, 30, 11-28. https://doi.org/10.4314/just.v30i2.60538

[5] Eriksen, A.B. and Kjeldby, M. (1987). A Comparative Study of Urea Hydrolysis Rate and Ammonia Volatilization from Urea and Urea Calcium Nitrate. Fertilizer Research, 11, 9-24. https://doi.org/10.1007/BF01049561

[6] Cai, Z., Wang, B., Xu, M., Zhang, H., Zhang, L. and Gao, S. (2014) Nitrification and Acidification from Urea Application in Red Soil (Ferralic Cambisol) after Different Long-Term Fertilization Treatments. Journal of Soils and Sediments, 14, 1526-1536. https://doi.org/10.1007/s11368-014-0906-4

[7] Krajewska, B. (2009) Ureases I. Functional, Catalytic and Kinetic Properties: A Review. Journal of Molecular Catalysis B: Enzymatic, 59, 9-21.

https://doi.org/10.1016/j.molcatb.2009.01.003

[8] Brady, N.C. and Weil, R.R. (2008) The Nature and Properties of Soils, 360. Upper Saddle River: Pearson Prentice Hall.

https://1642598126.rsc.cdn77.org/sites/tbbooks/pdf/Solutions-Manual-Nature-Prop erties-of-Soils-14th-Edition-Brady.pdf

[9] Van Kessel, M.A., Speth, D.R., Albertsen, M., Nielsen, P.H., den Camp, H.J.O., Kartal, B. and Lücker, S. (2015) Complete Nitrification by a Single Microorganism. Nature, 528, 555. https://doi.org/10.1038/nature16459

[10] Zhang, J., Wu, P., Hao, B. and Yu, Z. (2011) Heterotrophic Nitrification and Aerobic Denitrification by the Bacterium Pseudomonas Stutzeri YZN-001. Bioresource Technology, 102, 9866-9869. https://doi.org/10.1016/j.biortech.2011.07.118

[11] Lozinov, A. and Ermachenko, V. (1959) Relation of the Process of Oxidation of Ammonium Ion by Nitrite Bacteria to Certain Factors of the Medium. I. Effect of Concentrations of Ammonium Sulfate. Mikrobiologiia, 28, 724.

[12] Sharma, B. and Ahlert, R.C. (1977) Nitrification and Nitrogen Removal. Water Re- 
search, 11,897-925. https://doi.org/10.1016/0043-1354(77)90078-1

[13] Chang, E.-H., Chung, R.-S. and Tsai, Y.-H. (2007) Effect of Different Application Rates of Organic Fertilizer on Soil Enzyme Activity and Microbial Population. Journal of Soil Science and Plant Nutrition, 53, 132-140. https://doi.org/10.1111/j.1747-0765.2007.00122.x

[14] Steiner, C., Glaser, B., Geraldes, T.W., Lehmann, J., Blum, W.E. and Zech, W. (2008). Nitrogen Retention and Plant Uptake on a Highly Weathered Central Amazonian Ferralsol Amended with Compost and Charcoal. Journal of Plant Nutrition and Soil Science, 171, 893-899. https://doi.org/10.1002/jpln.200625199

[15] Cameron, K.C., Di, H.J. and Moir, J.L. (2013) Nitrogen Losses from the Soil/Plant System: A Review. Annals of Applied Biology, 162, 145-173.

https://doi.org/10.1111/aab.12014

[16] Stolarski1, R.S., Douglass, A.R., Oman, L.D. and Waugh, D.W. (2015) Impact of Future Nitrous Oxide and Carbon Dioxide Emissions on the Stratospheric Ozone Layer. Environmental Research Letters, 10, 034011. https://doi.org/10.1088/1748-9326/10/3/034011

[17] Bala, P., Bhardwaj, S.S. and Sidhij, P.S. (2000) Effect of Electrolyte PH on Phosphate Adsorption by Soils. Asian Journal of Chemistry, 12, 394-398.

[18] Zeng, Q.R., Liao, B.H., Zhang, L.T., Zhou, X.H. and Tang, H.X. (2006) Short-Term Alleviation of Aluminum Phytotoxicity by Urea Application in Acid Soils from South China. Chemosphere, 63, 860-868.

https://doi.org/10.1016/j.chemosphere.2005.07.056

[19] Fan, M.X., MacKenzie, A.F. and O'Halloran, I.P. (1993) Phosphorus Sorption as Influenced by Added Urea in Two Eastern Canadian Soils. Soil Science Society of America Journal, 57, 1218-1222. https://doi.org/10.2136/sssaj1993.03615995005700050010x

[20] Pereira, E.A.O., Melo, V.F., Abate, G. andMasini, J.C. (2019) Adsorption of Glyphosate on Brazilian Subtropical Soils Rich in Iron and Aluminum Oxides. Journal of Environmental Science and Health, Part B, 54, 906-914. https://doi.org/10.1080/03601234.2019.1644947 